\title{
EFFECTS OF SMALL RODENTS AND LARGE MAMMALS ON NEOTROPICAL SEEDS
}

\author{
Elizabeth A. DeMattia, ${ }^{1}$ Lisa M. Curran, and Beverly J. Rathcke \\ Department of Ecology and Evolutionary Biology, University of Michigan, 830 North University, Ann Arbor, \\ Michigan 48109-1048 USA
}

\begin{abstract}
The direct and indirect effects of seed predation by a Neotropical community of small rodents and large mammals were examined in a 1.5-year exclosure experiment in Corcovado National Park, Costa Rica. This park has an intact terrestrial mammalian community, including small rodents and large mammalian seed predators, an essential condition to quantify the dynamics of seed predation. To measure seed predation, three exclosure treatments $(1.2 \mathrm{~m}$ radius $\times 1.5 \mathrm{~m}$ tall $)$ in two forest types (primary vs. secondary forest) were monitored: (1) fenced exclosures that excluded large mammals, (2) fenced exclosures that excluded both large and small mammals, and (3) open controls. Tethered seeds were added from nine common species of canopy trees and lianas (seven families), and seed removal was measured from February 2001 to July 2002. Small rodents had significant negative effects on four of the nine seed species tested, and the effects of small rodents on seed predation differed significantly from the effects of large mammals and insect/fungal pathogens. Small-rodent seed predation (both rates and total proportion destroyed) did not differ between secondary and primary forest habitats. Throughout the exclosure study, small-rodent populations were marked and recaptured to document their community composition and densities. Small-rodent population fluctuations were observed, and shifts in composition directly affected species-specific and community-wide seed predation. Fewer seeds were destroyed when small-rodent abundance was low. Small-rodent population fluctuations also had an indirect effect, reversing the relative importance of small rodents and large mammals and resulting in large mammals becoming the primary seed predators. This change did not only decrease total seed predation for some species; it had the additional effect of moving from a primarily negative interaction (seed predation from the small rodents) to the varied interactions of seed predation and seed dispersal (scatter-hoarding). This research illustrated that small-rodent community fluctuations are a mechanism responsible for variability in the process of Neotropical seedling regeneration.
\end{abstract}

Key words: Brosimum costaricanum; Clarisia racemosa; Costa Rica; Heteromys desmarestianus; Oryzomys talamancae; primary forest; Proechimys semispinosus; recruitment fluctuations; scatterhoarders; seed predation; tropical and secondary forest; Virola koshnyi.

\section{INTRODUCTION}

A fundamental challenge for community ecologists is to understand the forcing mechanisms that determine the distribution and abundance of organisms. Major shifts in an organism's diversity, coexistence, behavior, and recruitment can result from plant-animal interactions across trophic food webs (Lubchenco 1978, Davidson et al. 1984, Heske et al. 1994). Because plantanimal interactions can be positive and/or negative and are context dependent, research that aims to quantify such direct and indirect interactions is extremely important in determining community dynamics (Janzen 1971, Soulé and Terborgh 1999).

One such plant-animal interaction, seed predation by terrestrial mammals, has been well studied and shown to directly influence plant recruitment (Whelan et al. 1991, Forget 1993, Heske et al. 1994, Ostfeld et

Manuscript received 15 April 2003; revised 2 October 2003; accepted 25 October 2003; final version received 16 January 2004. Corresponding Editor: D. A. Spiller.

${ }^{1}$ E-mail: mede@umich.edu al. 1997, Curran et al. 1999, Curran and Leighton 2000, Curran and Webb 2000, Howe and Brown 2001, Schnurr et al. 2002). While the negative aspect of seed predation by large and small mammals has been well documented, mammalian seed predators can also positively interact with plants via scatter-hoarding and seed caching (VanderWall 1993, Forget 1993, 1994, Adler and Kestell 1998, Brewer and Rejmánek 1999), and this interplay between the positive and negative effects of mammalian seed predation needs to be quantified. This is especially true in tropical communities due to the diversity of terrestrial seed-eating mammals and the complexity of their food webs (Wright et al. 2000, Brewer and Webb 2001).

In Neotropical forests, terrestrial mammalian seed predators range from the large-bodied white-lipped peccaries $(\sim 35 \mathrm{~kg})$ down to small rodents $(<700 \mathrm{~g})$. While many different Neotropical mammalian species contribute to seed predation (Forget 1993, 1994, Asquith et al. 1997, 1999, Wright et al. 2000, Wright and Duber 2001), to date, few studies have quantified dif- 
ferences in how these groups of seed predators interact. Most empirical research on Neotropical forest seed predation has focused on large terrestrial mammalian seed predators $(>750 \mathrm{~g})$, such as paca (scatter-hoarder), agouti (scatter-hoarder), and peccaries (seed predator) (Forget 1993, 1994, Forget et al. 1999, Asquith et al. 1997, 1999, Wright et al. 2000, Altrichter et al. 2001, Wright and Duber 2001). Fewer studies have described the effects that small rodents have on seed predation, despite their predicted role in potential seed loss in Neotropical forests (Terborgh et al. 1993). The majority of Neotropical small-rodent seed predation research has focused solely on the medium-bodied Heteromys desmarestianus (46-87 g) or the large-bodied Proechimys semispinosus (320-536 g) (Vandermeer 1979, Adler and Seamon 1991, Adler and Kestell 1998, Lambert and Adler 2000, Brewer and Webb 2001). These two species are important seed predators and in some instances seed scatter-hoarders, but Neotropical forests support a diverse rodent community including several other small- and medium-sized rodents from genera such as Peromyscus, Oryzomys, Melanomys, Rhipidomys, Oecomys, Zygodontomys, and Sigmodon (Fleming $1974 a, b$, Terborgh et al. 1993, Reid 1997, Wenny 2000). Overall, these smaller bodied rodents (8-130 g) are more specialized in their seed consumption and are mainly seedeaters. Because as many as five rodent species (within the Murid family) are found within any Neotropical forest assemblage (Reid 1997), small-rodent communities have the potential to create a heterogeneous effect on seed predation patterns, and thus, seed survival and seedling recruitment. However, the relative role of the full complement of small rodents within the seed predator guild has not been quantified to date.

The importance of small-bodied rodents may have been overlooked because these rodents may prefer small seeds ( $<30 \mathrm{~mm}$ width), and the majority of Neotropical seed predation experiments have focused on large-seeded plant species (30-100 mm), a size easier to manipulate in seed predation studies and consumed by large, mammalian seed predators (Forget 1993, 1994, Terborgh et al. 1993, Adler and Kestell 1998, Brewer and Rejmánek 1999, Brewer and Webb 2001, Wright et al. 2000). In contrast to these previous studies, this study provides a comprehensive study of mammalian seed predation by examining the entire terrestrial mammalian community and by experimentally manipulating seed predation using seeds across both a size spectrum and from numerous plant families. Moreover, by investigating the effects of small-rodent seed predation combined with that of scatter-hoarding by large mammals, this study examines the direct and indirect interactions between small rodents and large mammals, and their effects on seed fate.

The effects of seed predation by a Neotropical community of small rodents and large mammals were tested by the following hypotheses and predictions: (1) If small rodents and large mammals have low dietary overlap, then the exclusion of large mammals will (a) change the relative proportion of seed species that are eaten, and (b) reduce overall seed predation. (2) If habitat (primary vs. secondary forest) does not affect small-rodent diversity and abundance, then small-rodent seed predation rates should be similar across habitats. (3) If large mammals scatter-hoard more frequently than small rodents, then the exclusion of large mammals will increase the proportion of seeds destroyed. (4) If there is a direct and positive relationship between small-rodent populations and seed predation rate, then seed predation should increase when smallrodent populations are most abundant (i.e., greatest biomass).

\section{Methods}

\section{Site description}

Field studies were conducted at Sirena Biological Station, Corcovado National Park (CNP), Costa Rica $\left(8^{\circ} 28^{\prime} 49^{\prime \prime} \mathrm{N}, 83^{\circ} 35^{\prime} 22^{\prime \prime} \mathrm{W}\right)$. The region, described as tropical wet forest, receives $>5 \mathrm{~m}$ of rain annually with the majority of rain falling during the annual rainy season (August-December). The dry season extends from January through March with average rainfall ranging from 10 to $75 \mathrm{~mm}$ (Sirena Biological Station, unpublished data). The area supports a forest canopy $30-70 \mathrm{~m}$ tall. Given the large area (54 500 ha) and the national park status of CNP, the wildlife has been protected and contains a community of post-dispersal, terrestrial seed predators that has not suffered from local extinctions (including the endangered white-lipped peccary, Dicotyles pecari; Reid 1997: CITES appendix I). This intact mammalian community (Dicotyles pecari, Tayassu tajacu, Dasyprocta punctata, and Agouti paca) provided an ideal system for quantifying the dynamics of small-rodent and large-mammalian seed predation.

In addition to the protected wildlife, Sirena Biological Station has a unique land-use history that allowed comparison of small-rodent seed predation in primary and late-secondary successional forests (sensu Richards 1952). When the park was created in October $1975, \sim 10 \%$ of the park was comprised of farmsteads, where the dominant activity was subsistence agriculture and cattle ranching (Phillips 1989). These formerly cultivated lands have been undergoing succession since 1975. The demarcation of both primary and secondary forested habitats was determined using historical information, settlement maps, aerial infrared photographs (Phillips 1989), and ground-truthed tree censuses. These data on adult tree diversity (DeMattia 2004) coupled with historical land-use information provided an accurate, fine-grained habitat typing for comparison of patterns of small-rodent seed predation in secondary forest and primary forest habitats. 


\section{Small-rodent seed predation trials}

To investigate seed predation on a suite of canopy species' seeds, three treatments were established in the two forest types. The first treatment isolated smallrodent effects by excluding large mammals ( $\mathrm{SR}=$ small-rodent access). Large mammals were excluded using circular wire fencing $(1.2 \mathrm{~m}$ radius $\times 1.5 \mathrm{~m}$ tall $)$ with an opening along the bottom edge $(10 \mathrm{~cm}$ in height) that allowed small-rodent access. The second treatment was an open control that allowed both largemammal and small-rodent access (LMSR = largemammal and small-rodent access). The third treatment, a closed control, was implemented during the March 2001 seed trials and quantified ant and fungal predation by excluding both small rodents and large mammals $($ CLOSED $=$ closed to mammals $)$. Small rodents and large mammals were excluded using circular wire fencing $(2 \mathrm{~m}$ radius $\times 1.5 \mathrm{~m}$ tall) closed along the top edge, a design that enabled access by insects and fungal spores. This was an incomplete factorial design because it was not feasible to exclude rodents and not exclude the large mammals.

Within each primary and secondary forest habitat, a total of eight randomly separated "exclosure blocks", were monitored from February 2001 to July 2002. Blocks were separated by at least $30 \mathrm{~m}$ (based on home range estimates and mark-recapture data; DeMattia 2004). Each exclosure block had one open control (LMSR), one large-mammal exclosure (SR), and one large-mammal and small-rodent exclosure (CLOSED). Each treatment had a small plastic platform $(10 \times 10$ $\mathrm{cm})$ with as many as eight spool-line treatments. Spoolline treatments had nylon thread (from a bobbin inside a plastic case) attached to each seed. Each seed carried from the platform was located using the trail of nylon thread. Field tests in 2000 verified that gluing string did not affect seed removal rates.

For each seed species, fruits were collected from at least three fruiting adult individuals within the same week, and then all fruits of the same species were combined to ensure a random selection of fruits from different adults. The collected fruits were prepared for trials by: (1) removal of their pericarp and/or aril so that only their seed was present; (2) inspection for insect and fungal damage (any seed that floated in water or had an insect exit hole was rejected); (3) drying (placed in the sun for at least four hours); and (4) attachment to the bobbin string using Super Glue gel formula. Platforms were then placed in each treatment, and seeds were monitored on day $1,2,7,14,21$, and 28. After day 28 , all seeds and platforms were removed. This sampling design was determined from average germination rates; the majority of seeds were either destroyed or germinated by day 28 . This design permitted an evaluation of seed fate: determining whether the seed was moved, eaten (destroyed), buried (scatterhoarded), cached (destroyed), or germinated. Seeds were considered moved if they were $>1 \mathrm{~m}$ from the platform. Seeds were considered eaten if more than half of the seed was removed. Buried (scatter-hoarded) seeds were considered any seed that was $>1 \mathrm{~m}$ away from the platform and buried just beneath the soil or under leaf litter. Cached seeds, those seeds moved into a burrow and $>10 \mathrm{~mm}$ below the soil surface were considered moved and destroyed, as $10 \mathrm{~mm}$ was too deep for successful germination to ensue (E. A. DeMattia, personal observation). Insect destruction (e.g., weevils leave exit holes and ants hollow out the seed leaving a thin shell) was noted and can be distinguished from mammal destruction (e.g., signs of gnawing). Most seeds, seed parts, and/or spool-line ends (the part of the string with glue still attached) were located $(>95 \%)$. The remaining "lost" seeds were removed from analyses as their fate could not be accurately detected (i.e., the string was snagged and cut, and/or seed parts/glue end of the string was not found).

In 2001, small-rodent seed predation was examined for a suite of canopy tree and liana species' seeds during three seed predation trials (Table 1). Plant species tested were: Pithecoctenium crucigerum (L.) A.H. Gentry, Erythrina costaricensis Micheli, Brosimum costaricanum Liebm., Sarcaulus brasiliensis (A. DC.) Eyma, Terminalia oblongata (Ruiz \& Pav.) Steud., Synthecanthus warsewiczianus $\mathrm{H}$. Wendl., Virola koshnyi Warb., Cynometra hemitomophylla (Donn. Sm.) Britton \& Rose, and Clarisia racemosa Ruiz \& Pav. (Table 1). Only species in seed trials after March 2001 were included in statistical analyses because CLOSED treatments were added in March 2001. This does not bias the data because only two species were not retested $(P$. crucigerum and $S$. brasiliensis) and these were not consumed by small rodents, but rather by ants and fungal pathogens. The above seed species were selected because they represent a broad range of plant families (seven families) and seed sizes (7.68-44.4 $\mathrm{mm}$ in length) and are an important component of the canopy diversity within CNP (R. Aguilar, personal communication). The selected species were grouped based on the quantity of fruits available for manipulation experiments at specific times.

\section{Quantifying scatter-hoarding by large mammals and small rodents}

Scatter-hoarding activity was quantified by analyzing all seeds that were moved from the seed platform and buried under leaves or soil. To discriminate scatterhoarding activity (potential dispersal) from seed predation, analyses included only seeds that were scatterhoarded and survived at least one day. Those seeds that were moved and destroyed within the same day were not considered scatter-hoarded.

\section{Quantifying small-rodent abundance}

The small-rodent community was monitored for three rainy seasons (July 2000, August 2000, June 
TABlE 1. Canopy plant species in each of the three seed-predation trials Seed size and observation of seed predation by small rodents are also reported.

\begin{tabular}{|c|c|c|c|c|c|}
\hline $\begin{array}{l}\text { Seed trial } \\
\text { group } \dagger\end{array}$ & Family & Species & $\begin{array}{l}\text { Voucher } \\
\text { numbers } \$\end{array}$ & $\begin{array}{l}\text { Seed length } \\
\quad(\mathrm{mm}) \S\end{array}$ & $\begin{array}{c}\text { Seeds destroyed } \\
(\%) \|\end{array}$ \\
\hline \multirow[t]{4}{*}{ Feb 2001} & Bignoniaceae & Pithecoctenium crucigerum & 4827 & $9.81 \pm 0.77$ & NA \\
\hline & Fabaceae (Pap) & Erythrina costaricensis & 42 & $10.2 \pm 0.74$ & NA \\
\hline & Moraceae & Brosimum costaricanum & 3764 & $9.65 \pm 1.44$ & NA \\
\hline & Sapotaceae & Sarcaulus brasiliensis & 4878 & $27.6 \pm 2.24$ & NA \\
\hline \multirow[t]{4}{*}{ Mar 2001} & Fabaceae (Pap) & Erythrina costaricensis & 42 & $10.2 \pm 0.74$ & 3 \\
\hline & Moraceae & Brosimum costaricanum & 3764 & $9.65 \pm 1.44$ & 56 \\
\hline & Combretaceae & Terminalia oblongata & 222 & $7.68 \pm 1.08$ & 3 \\
\hline & Arecaceae & Synthecanthus warscewiczianus & 4981 & $10.1 \pm 0.73$ & 9 \\
\hline \multirow[t]{3}{*}{ Jun 2001} & Myristicaceae & Virola koshnyi & 3082 & $17.8 \pm 1.57$ & 78 \\
\hline & Fabaceae (Caes) & Cynometra hemitomphylla & 3480 & $44.4 \pm 3.01$ & 25 \\
\hline & Moraceae & Clarisia racemosa & 5698 & $19.2 \pm 1.47$ & 59 \\
\hline
\end{tabular}

$\dagger$ Seed trials in February did not include the closed treatment.

\% Voucher specimens were collected and identified by Reinaldo Aguilar, INBIO Herbarium, San Jose, Costa Rica.

$\S$ Seed length was calculated as the longest dimension of the seed. Values are expressed as means \pm 1 SE.

$\|$ Percentage small-rodent seed predation $=$ percentage of seeds destroyed in the large-mammal exclosure (SR) - percentage of seeds destroyed in the closed treatment (CLOSED). NA $=$ not applicable.

2001, July 2001, and June 2002) and two dry seasons (February 2001, March 2001, February 2002, and March 2002). Two permanent traplines were established in June of 2000: one in secondary forest habitat (labeled SF and located at $8^{\circ} 28.960^{\prime} \mathrm{N}, 83^{\circ} 35.569^{\prime} \mathrm{W}$ ) and one in primary forest habitat (labeled PF and located at $8^{\circ} 29.186^{\prime} \mathrm{N}, 83^{\circ} 35.315^{\prime} \mathrm{W}$ ). Each trapline was $200 \mathrm{~m}$ in length and consisted of 20 trap stations placed every $10 \mathrm{~m}$. Each trap station contained one Tomahawk $(11.2 \times 11.2 \times 35.8 \mathrm{~cm}$; Tomahawk Live Trap Company, Tomahawk, Wisconsin, USA) and one Sherman $(7.3 \times 7.8 \times 20.2 \mathrm{~cm}$; H.B. Sherman Traps, Incorporated, Tallahassee, Florida, USA) trap placed within 2 $\mathrm{m}$ of the trap station. Traps were baited with whole sunflower seeds, and each trapping session lasted $10 \mathrm{~d}$ for a total of 400 trap nights/trapping session. Trapping sessions at SF and PF were conducted simultaneously so that trapping data were controlled for rainfall, temperature fluctuations, and moonlight.

Trapping sessions ( $10 \mathrm{~d}$ each) were conducted at both SF and PF during both the dry and wet seasons for three years. In addition to the SF and PF traplines, two replicate traplines were also monitored: one in primary forest (A) and one in secondary forest (B). Trapline A was located $230 \mathrm{~m}$ away from PF but still within primary forest habitat, and trapline B was located $207 \mathrm{~m}$ away from SF but still within secondary forest habitat. Replicate traplines were identical in structure to the permanent traplines (200 m long with 20 trap stations), and were monitored at two periods during the threeyear study. Thus, a total of 8800 trap nights were accumulated during 22 trapping sessions distributed equally across three rainy and two dry seasons for a total of 11 sampling months.

Each captured rodent was identified, weighed, sexed, and permanently marked. Voucher specimens of each species were deposited in the University of Michigan Museum of Zoology (UMMZ voucher numbers 174801-174815). From these data, we compared the relative abundances of small-rodent species by estimating total number of individuals per area (number of individuals trapped during each trap session/area of the trap session). In addition we also compared relative community composition and relative community biomass (sum of number of each species per trap session $\times$ species-specific mean mass/area of the trap session).

\section{Quantifying seed predation and small-rodent abundance}

We examined whether a change in the small-rodent community (specifically the local population crash in the small-bodied Oryzomys talamancae) caused interannual variation in the intensity of seed predation for three particular tree species. This was accomplished by comparing species-specific seed predation rates in 2002 to trials in previous years when $O$. talamancae abundance was high. We chose three plant species (B. costaricanum, V. koshnyi, and C. racemosa) based on their high small-rodent seed predation rates in 2001: 56$78 \%$ of the seeds were destroyed. The seed predation trials in 2002 were conducted with the same treatments and in the same location as the trials in 2001. However, in 2002, each species was tested separately. Although the 2002 trials differ from the 2001 trials (only one species was present on the spool-line platform), the number of each species tested per platform was held constant across years.

\section{Data Analysis}

\section{Comparison of seed predation in 2001}

Using data from March and June 2001 seed trials, resampling was used to determine pairwise differences between treatments for each species as these data were categorical not normal (Appendix A). In addition, relative rates of seed predation (time until seed destruction; i.e., hazard ratio) were compared using the survival analysis Cox regression (SAS 5.0, SAS Institute, 


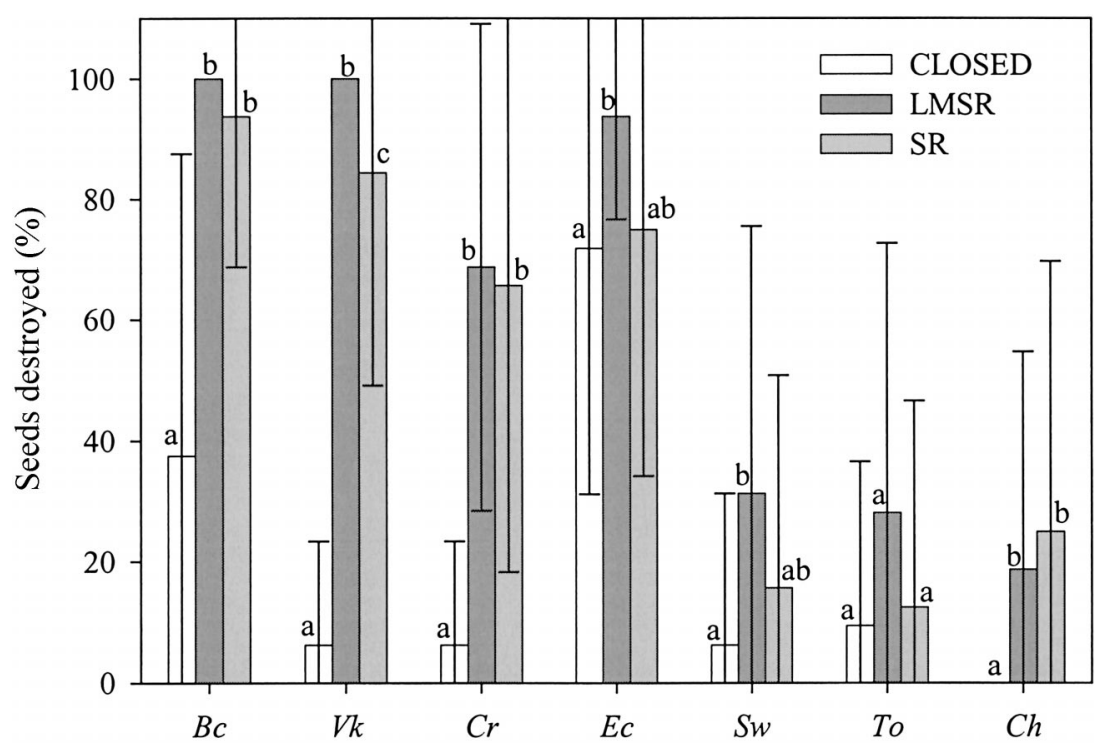

FIG. 1. Percentage of seeds destroyed (mean per platform) in the different 2001 treatments: CLOSED (closed to mammals), LMSR (large mammals and small-rodent access), and SR (small-rodent access). Seeds tested included: Bc, Brosimum costaricanum; Vk, Virola koshnyi; Cr, Clarisia racemosa; Sw, Synthecanthus warscewiczianus; Ec, Erythrina costaricensis; To, Terminalia oblongata; and Ch, Cynometra hemitomophylla. Significant differences (from resampling) among treatments within each species are indicated by letters $(P<0.05)$. Error bars indicate \pm 1 SD.

Cary, North Carolina, USA). Cox regression determines and compares relative rates of seed predation for different seed species, in different forest types, and with different block-designed treatments. SAS was chosen based on its ability to perform an Efron approximation for noncontinuous data (a more conservative/exact estimator; Allison 1995). Cox regression does not assume data normality (unlike logistic regression) and censors data such that seeds surviving to germination (i.e., not destroyed) were not ignored or assumed destroyed, but contributed to the estimated hazard ratio (Allison 1995).

For the general Cox regression model, all species in the March 2001 and June 2001 seed trials were examined and tested for differences among species (Erythrina costaricensis, Brosimum costaricanum, Synthecanthus warscewiczianus, Virola koshnyi, Cynometra hemitomophylla, and Clarisia racemosa), between forest type (primary vs. secondary), and among treatments (CLOSED, SR, and LMSR). Differences among blocks (1-16) were examined using a random factor (COVSANDWICH estimator; Allison 1995).

\section{Differences in scatter-hoarding between large mammals and small rodents}

Differences in scatter-hoarding activity among the CLOSED, LMSR, and SR treatments were analyzed through resampling (Appendix A).

\section{Comparison of seed predation rates between 2001 and 2002}

Using resampling and Cox regression analyses, seed predation rates in 2001 were compared with those in 2002 (Appendix A).

\section{RESUltS}

Comparison of seed predation in 2001

Species-specific pairwise comparisons of the treatments found that there was a significant difference in the relative proportion of seeds destroyed in the SR treatment when compared to the CLOSED treatment for V. koshnyi $(P=0.0001)$, B. costaricanum $(P=$ $0.0318)$, and $C$. racemosa $(P=0.01)$. In other words, all three species had significant increases in the number of seeds destroyed when small rodents had access to their seeds (Fig. 1; Cox regression results paralleled those from the species-specific resampling analyses: Appendix B). In addition, species-specific pairwise comparisons between the LMSR and the CLOSED treatments found that six species $(B$. costaricanum, $P$ $=0.0002 ;$ V. koshnyi, $P<0.0001 ; C$. racemosa, $P<$ $0.0001 ;$ E. costaricanum, $P=0.0328 ; S$. warsewiczianus, $P=0.0353$; $C$. hemitomophylla, $P=0.0310$ ) had significantly higher seed predation in the LMSR treatment than the CLOSED treatment (Fig. 1). However, species-specific pairwise comparisons between the LMSR and the SR treatments found that only $E$. costaricensis displayed a significant decrease in total seed predation when large mammals were excluded ( $P$ $=0.0081$; Fig. 1 ). This was due to the negative indirect effect of the large-mammal gnawing, which destroyed seed coats or testas. Once the large-mammal gnaw marks exposed the endocarp, ants (Solenopsis spp.) were able to gain access to the seed and destroy it (a distinctive hollowed out seed with the red, protective coat still present). While total seed destruction for $E$. costaricensis between the SR and CLOSED treatments 


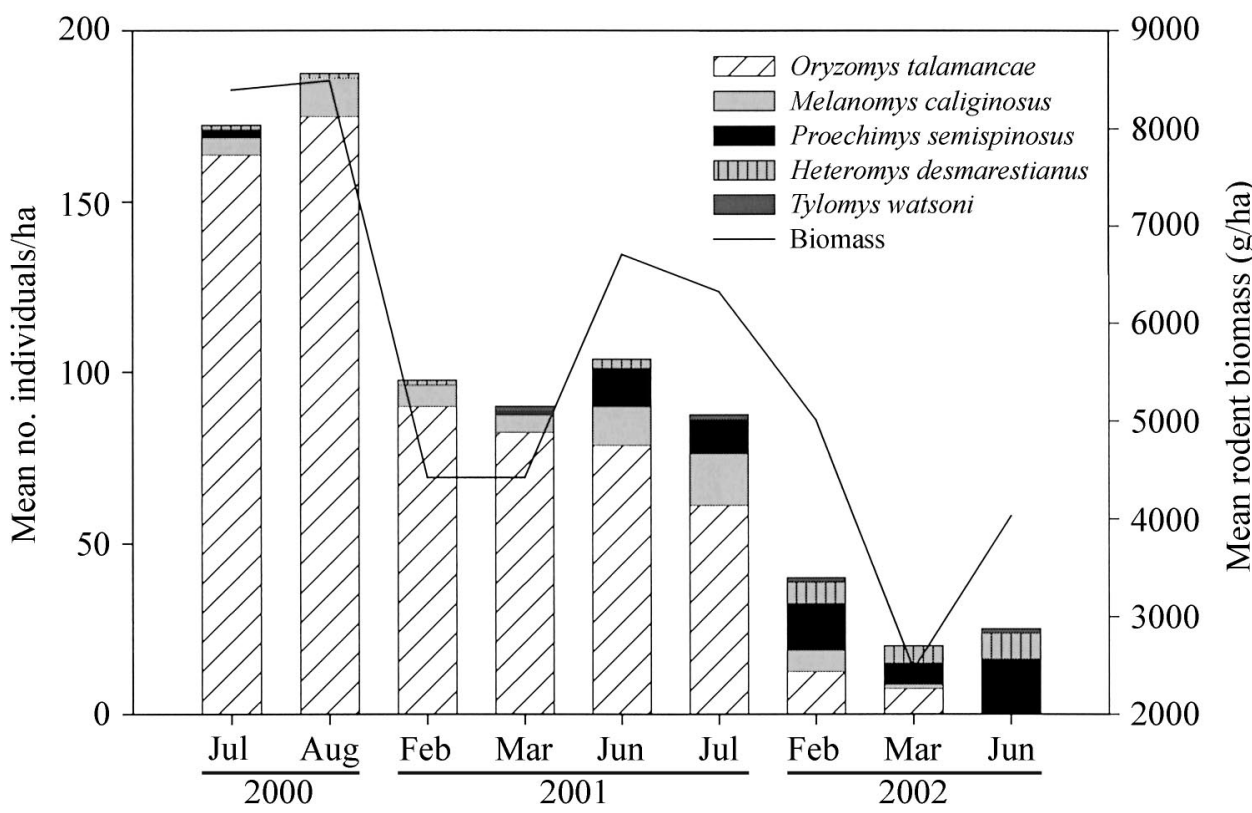

FIG. 2. Small-rodent community composition from July 2000 to June 2002. No significant difference was detected between the rodent community in the primary and secondary forest habitats; therefore, the data presented here represent the mean for both habitats. There were 8800 trap nights and 648 unique individuals captured in both habitats. Mean biomass is the relative biomass for each trap session divided by the number of trap sessions.

did not differ significantly, the destruction rate for the SR treatment was slightly higher than the CLOSED treatment (Appendix C). In general, ant predation required longer time periods than did mammal predation and was typically evident after week two.

In the general Cox regression model, habitat (primary vs. secondary) was not shown to have an effect on seed predation $(P=0.878$; adjusting for treatment and species and including block as a random factor in the Cox regression). In addition, when $B$. costaricanum, C. racemosa, E. costaricensis, and V. koshnyi (the four species that had significant seed predation rates in the general model) were each analyzed separately, there was still no effect of habitat on seed predation $(P>0.4$ for each species $)$.

\section{Scatter-hoarding and movement of seeds in 2001}

In 2001, scatter-hoarding affected $<12 \%$ of all seeds tested and there was no significant effect of higher scatter-hoarding in the LMSR treatment when compared to the SR or CLOSED treatment for any species.

\section{Seed predation and small-rodent abundance}

Small-rodent sampling (over three rainy seasons and two dry seasons) showed that significant annual and interannual species-specific variability altered the species composition of the community (Fig. 2). In 2000 and 2001, the small-bodied Oryzomys talamancae (47$74 \mathrm{~g}$ ) was the most abundant small rodent and the most common seed predator. In 2002, the large-bodied Proechimys semispinosus (320-536 g) and medium-bodied Heteromys desmarestianus (46-87 g; the only species with external check pouches) were the most abundant small rodents and the most prevalent seed predators; few $O$. talamancae individuals were captured in 2002. These population dynamics proved to be critical for interpreting our results in 2002 , because the majority of seed predation events in 2000 and 2001 were attributed to $O$. talamancae. In addition, total community biomass fluctuated from $8395 \mathrm{~g} / \mathrm{ha}$ in the 2000 rainy season to $3736 \mathrm{~g} / \mathrm{ha}$ during the 2002 dry season, and to $4030 \mathrm{~g} / \mathrm{ha}$ during the 2002 rainy season (Fig. 2).

The fluctuations in the small-rodent community composition in 2002 resulted in an overall decrease in seed predation by small rodents. While small-rodent seed predation (SR) decreased for all seed species tested $(C$. racemosa, B. costaricanum, and $V$. koshnyi), total seed predation (LMSR treatment) decreased significantly during 2001 and 2002 for only $C$. racemosa $(P=$ 0.0042 ; Fig. 3). In contrast, total seed predation (LMSR) was similar in both 2001 and 2002 for $B$. costaricanum. In 2001, small rodents caused B. costaricanum seed predation; while in 2002 the primary agents of seed destruction were ants and fungal pathogens (Fig. 3; CLOSED treatment did not differ from LMSR and SR treatments). As in B. costaricanum, small rodents preyed upon $V$. koshnyi seeds in 2001. In 2002, however, small-rodent seed predation on $V$. koshnyi decreased and large-mammal seed predation increased (Fig. 3). Furthermore, ants and fungal pathogens were never significant seed destroyers of V. koshnyi in either 2001 or 2002. All Cox regression results paralleled those from the species-specific resampling analyses (Appendix D). 


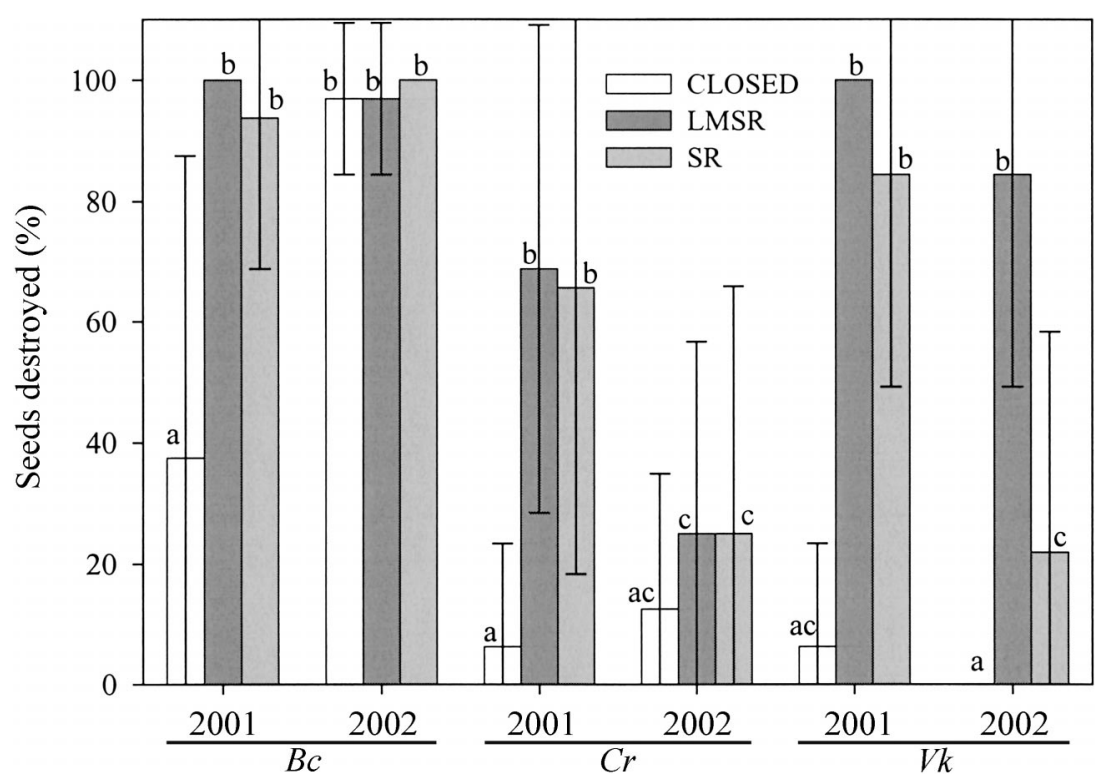

FIG. 3. Percentage of $B c, B$. Costaricanum; $C r, C$. Racemosa; and $V k, V$. koshnyi seeds destroyed (mean per platform) in the CLOSED, LMSR, and SR treatments during 2001 and 2002. See Fig. 1 for abbreviations. Significant differences (from resampling) among treatments and years but within each species are indicated by letters $(P<0.05)$. Error bars indicate \pm 1 SD.

\section{Scatter-hoarding and movement of seeds in 2002}

In 2002 , C. racemosa was the only seed species tested that had significantly higher scatter-hoarding in the LMSR treatment than in the SR treatment $(P=0.0230$; Fig. 4).

\section{DISCUSSION}

Data presented here indicate that small-rodent communities have significant effects on post-dispersal seed predation, and thus, on seedling recruitment in Neo-

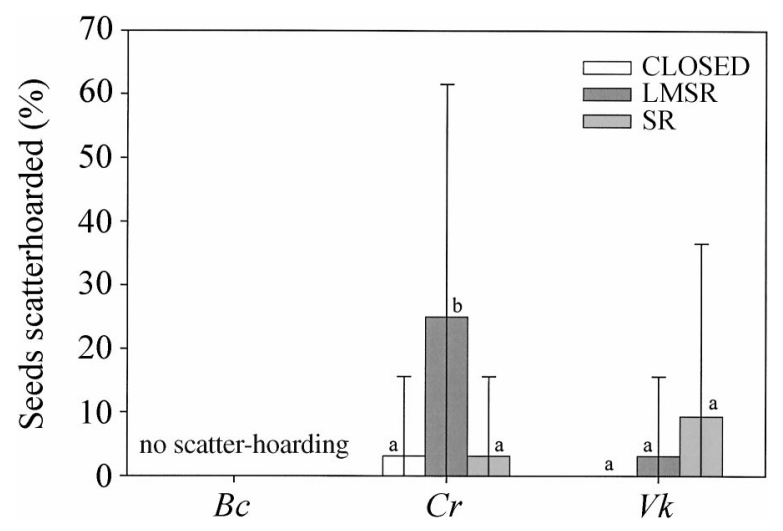

FIG. 4. Percentage of seeds scatter-hoarded (mean per platform) in the 2002 CLOSED, LMSR, and SR treatments (see Fig. 1 for abbreviations). Seeds tested included: $B c$, Brosimum costaricanum $(P=1.00) ;$ Vk, Virola koshnyi $(P=$ $0.976)$; and $C r$, Clarisia racemosa $(P=0.010)$. Significant differences (from resampling) among treatments within each species are indicated by letters $(P<0.05)$. Error bars indicate $\pm 1 \mathrm{SD}$. tropical canopy tree communities. Small rodents had significant negative effects on four of the nine seed species tested. These results suggest a role for small Neotropical rodents similar to that documented for small rodents within temperate forest communities (Ostfeld et al. 1997, Howe and Brown 2001, Schnurr et al. 2002). Furthermore, the effect of small rodents on seed predation differed significantly from that of large mammals and insect/fungal pathogens. Although the majority of seed predation studies have examined only the role of large mammals and insects/fungal pathogens on seed survival in tropical forests (Forget 1993, 1994, Wills 1996, Asquith et al. 1997, 1999, Wright et al. 2000, Wright and Duber 2001), this study demonstrates that it is critical to include small-rodent seed predators in order to interpret the seedfall dynamics in tropical tree communities.

This study also demonstrates that small rodents partition resources with both large mammals and with insects (ants), and that this partitioning depends on smallrodent community composition. Furthermore, this experiment incorporated a range of seed sizes (7.7-44 $\mathrm{mm}$ in length), and demonstrated that both large mammals and small rodents were important scatter-hoarders and seed predators for two of the largest seeds in this study (C. racemosa and V. koshnyi). For the remaining seed species, however, small rodents and ants were the dominant seed predators, demonstrating seed size partitioning (ants and rodents consume smaller seeds than large mammals) similar to that documented for temperate desert communities (Davidson et al. 1984). This finding is especially important given that, on Barro 
Colorado Island, Panama (BCI), which is floristically similar to our site, at least $96 \%$ of animal dispersed seeds are small ( $<1 \mathrm{~g}$; Foster 1996). If small rodents and ants are the main predators for the spectrum of smaller seeds, then studies investigating only large mammals overlook critical selective factors, and thus, dynamics of seed fate for the overwhelming majority of plant species. In tropical forests, several levels of food web partitioning occur, and, therefore, future research on tropical seed predation should address the important interactions among large mammals, small rodents, insects, and their food webs.

The effects of seed predation by large mammals and insects/fungal pathogens have been shown to be sensitive to primary and secondary forested habitats. In general, predation is typically higher in secondary forests than primary forests (Hammond 1995, Hammond and Brown 1995, Notman et al. 1996, Wright et al. 2000, Wright and Duber 2001, Peña-Claros and de Boo 2002). However, results presented here demonstrate that small-rodent seed predation (both rates and total proportion destroyed) did not differ significantly in primary and secondary forested habitats. Even though small-rodent seed predation was similar between habitats, canopy tree distributions and fruiting patterns differed significantly between habitats. Reproductive adults for the seed species used in the seed trial experiments were not equally distributed between forest types. Of the seeds used, T. oblongata was found within the secondary forest habitat and one adult $V$. koshnyi was found in the transition area between forest types. All other seed species were collected within primary forest habitat. Therefore, ambient seed availabilities were not uniform between the forest types, and "secondary-forest rodents" may have had less available food and an underdeveloped search image for most of the seeds presented in the seed trials. Yet, seed predation rates by small rodents in both forest types were surprisingly similar, demonstrating that the intensity of small-rodent predation is driven by the demographics of the small-rodent community, not by short-term ambient seed levels. Long-term driving forces behind Neotropical small-rodent community fluctuations may be similar to temperate communities (Ostfeld and Keesing 2000, Schnurr et al. 2002), such that fruit production patterns may influence species-specific fluctuations of small-rodent populations (Adler 1998) creating lags or feedback cycles on multiyear intervals.

The community composition of small rodents was found to be a major factor influencing small-rodent seed predation. While total biomass of the small-rodent community remained relatively constant from 2001 to 2002, the community composition shifted from the small-bodied $O$. talamancae to the larger bodied $H$. desmarestianus and $P$. semispinosus. With this change in relative species composition, small-rodent seed predation decreased while seed predation by large mammals and ants increased. Hence, total seed predation within the community fluctuated from domination by small rodents to co-domination by a suite of agents: large mammals, small rodents, and insect/fungal pathogens. Although rarely employed in tropical plant-animal studies (but see Hoch and Adler 1997, Curran and Leighton 2000), both the biomass and composition of seed predators and their effects on prey (seeds) must be measured concurrently to determine these interactions and the specific context of these dynamics, especially in relatively short-term studies.

Brewer and Webb (2001) theorized that seed predation and scatter-hoarding of seeds could "interact with rodent population dynamics in the recruitment of seedlings." The results presented here not only corroborate their idea that small-rodent population fluctuations directly affect seed predation, but also show an indirect effect of small-rodent population fluctuations on seed predation; namely, a switch from small rodents to large mammals as the primary seed predators. This change not only decreases total seed predation for some species, it has the additional effect of moving from a primarily negative interaction (seed predation by the small rodents) to the varied interactions of seed predation (-) and scatter-hoarding (+) (Appendix E). This results from large mammals and larger bodied "small" rodents $(H$. desmarestianus and $P$. semispinosus) scatter-hoarding seeds significantly more than small-bodied "small" rodents and thus dispersing, as well as, destroying seeds. In 2001, almost all C. racemosa and $V$. koshnyi seeds were destroyed (65-100\%), and scatter-hoarding by large mammals imparted a relatively small effect $(\sim 5 \%)$. However, as the small-rodent community moved from small-bodied to large-bodied rodents, small-rodent seed predation decreased and scatter-hoarding activity increased for both small rodents and large mammals (10-25\%). This shift from mostly seed predation (a negative interaction on recruitment) to scatter-hoarding (a positive interaction on recruitment) provides a window of opportunity for possible regeneration. In addition, the interplay of scatter-hoarding and seed predation provides variability in the process of seedling regeneration influencing the intensity of recruitment limitation and possibly creating the "storage effect" of successful years interspersed with nonsuccessful years for subgroups of plant species, and thus, the mechanism creating recruitment fluctuations critical for maintaining canopy tree species' diversity (Chesson and Warner 1981, Hurtt and Pacala 1995).

Where large terrestrial mammals have been locally extirpated, diversity in the seedling stage decreased markedly. Such decreased diversity has been viewed primarily as the release from terrestrial mammalian herbivory, decreases in large-mammal scatter-hoarding, and hyper-abundant leaf cutter ant herbivory (Dirzo and Miranda 1991, Rao et al. 2001, Terborgh et al. 2001). However, this study has demonstrated that seedling recruitment is dependent not only on direct large- 
mammal and insect interactions (scatter-hoarding and herbivory), but also on the interplay between complex direct and indirect effects of scatter-hoarding by large mammals and small-rodent seed predation. As hunting and fragmentation increase, small rodents (which are not hunted) can persist within primary forest fragments and possess the potential for rapid recovery into secondary forested habitat (DeMattia 2004). Conversely, large mammals (with large home ranges) cannot persist in small primary forest fragments, and, therefore, cannot repopulate secondary regrowth habitats (Peres 2001). Consequently, as tropical forests become increasingly fragmented, the negative interactions between small rodents and seeds will dominate mammalian seed predation, thereby producing seedling carpets of species that are not eaten by small rodents. In this setting, small rodents will have the potential to affect seedling recruitment in fundamental ways, ultimately determining the composition and diversity of Neotropical forests.

\section{ACKNOWLEDGMENTS}

We thank the Area de Conservacion de Osa (ACOSA), Ministerio de Recursos Naturales, Energia, Y Minas, Corvado National Park, and CNP guards P. Valverde, P. Aleman, and E. Gonzales for research sponsorship. R. Aguilar, P. Myers, B. Munson, C. Guthrie, N. Gerardo, L. Buis-Kelley, A. Vegas, and L. Gilbert provided critical field and logistical support. Thanks to G. Estabrook and D. Schoolmaster for statistical advice. R. Burhnam, G. Paoli, A. Gorog, S. McCauley, G. Murray, O. Schmitz, D. Spiller, and two anonymous reviewers helped with editing. Trail system development and lab facilities at CNP were funded by NSF BSR-8315399, UT Austin's Institute for Latin American Studies Mellon grants program, and WWF. Financial support to E. DeMattia was from The Sophie Danforth Conservation Biology Fund, Rackham Graduate School at the University of Michigan (UM), The Latin and Caribbean Studies Department (UM), and the Department of Ecology and Evolutionary Biology (UM), and to L. M Curran by the Department of Ecology and Evolutionary Biology (UM).

\section{Literature Cited}

Adler, G. H. 1998. Impacts of resource abundance on populations of a tropical forest rodent. Ecology 79:242-254.

Adler, G. H., and D. W. Kestell. 1998. Fates of Neotropical tree seeds influenced by Spiny Rats (Proechimys semispinosus). Biotropica 30:677-681.

Adler, G. H., and J. O. Seamon. 1991. Distribution and abundance of a tropical rodent, the spiny rat, on islands in Panama. Journal of Tropical Ecology 7:349-360.

Allison, P. D. 1995. Survival analysis using the SAS system: a practical guide. SAS Institute, Cary, North Carolina, USA.

Altrichter, M., E. Carrillo, J. Saenz, and T. K. Fuller. 2001. White-lipped peccary (Tayassu pecari, Artiodactyla: Tayassuidae) diet and fruit availability in a Costa Rican rain forest. Revista de Biologia Tropica 49:1183-1192.

Asquith, N. M., J. Terborgh, A. E. Arnold, and C. M. Riveros. 1999. The fruits the agouti ate: Hymenaea courbaril seed fate when its disperser is absent. Journal of Tropical Ecology 15:229-235.

Asquith, N., S. Wright, and M. Clauss. 1997. Does mammal community composition control recruitment in Neotropical forests? Evidence from Panama. Ecology 78:941-946.
Brewer, S. W., and M. Rejmánek. 1999. Small rodents as significant dispersers of tree seeds in a Neotropical forest. Journal of Vegetation Science 10:165-174.

Brewer, S. W., and M. A. H. Webb. 2001. Ignorant seed predators and factors affecting the seed survival of a tropical palm. Oikos 93:32-41.

Chesson, P. L., and R. R. Warner. 1981. Environmental variability promotes coexistence in lottery competitive systems. American Naturalist 117:923-943.

Curran, L. M., I. Caniago, G. D. Paoli, D. Astianti, M. Kusneti, M. Leighton, C. E. Nirarita, and H. Haeruman. 1999. Impact of El Niño and logging on canopy tree recruitment in Borneo. Science 286:2184-2188.

Curran, L. M., and M. Leighton. 2000. Vertebrate responses to spatiotemporal variation in seed production of mastfruiting Dipterocarpaceae. Ecological Monographs 70:101128.

Curran, L. M., and C. O. Webb. 2000. Experimental test of the spatiotemporal scale of seed predation in mast-fruiting Dipterocarpaceae. Ecological Monographs 70:129-148.

Davidson, D. W., R. S. Inouye, and J. H. Brown. 1984. Granivory in a desert ecosystem: experimental evidence for indirect facilitation of ants by rodents. Ecology 65:17801786.

DeMattia, E. A. 2004. Effects of small rodents and large mammals on seed predation and seedling regeneration within primary and secondary Costa Rican forests. Dissertation. University of Michigan, Ann Arbor, Michigan, USA.

Dirzo, R., and A. Miranda. 1991. Altered patterns of herbivory and diversity in the forest understory: a case study of the possible consequences of contemporary defaunation. Pages 273-287 in P. W. Price, T. M. Lewinsohn, G. W. Fernandes, and W. W. Benson, editors. Plant-animal interactions: evolutionary ecology in tropical and temperate regions. John Wiley and Sons, New York, New York, USA.

Fleming, T. 1974a. The population ecology of two species of Costa Rican Heteromyid rodents. Ecology 55:493-520.

Fleming, T. 1974b. Social organization in two species of Costa Rican Heteromyid rodents. Journal of Mammalogy 55:543-561.

Forget, P. 1993. Post-dispersal predation and scatterhoarding of Dipteryx panamensis seeds by rodents in Panama. Oecologia 94:255-261.

Forget, P. 1994. Recruitment pattern of Voucapoua americana (Caesalpiniaceae), a rodent-dispersed tree species in French Guiana. Biotropica 26:408-419.

Forget, P. M., F. Mercier, and F. Collinet. 1999. Spatial patterns of two rodent-dispersed rain forest trees Carapa procera (Meliacece) and Vouacapoua americana (Caesalpiniaceae) at Paracou, French Guiana. Journal of Tropical Ecology 15:301-313.

Foster, R. B. 1996. The seasonal rhythm of fruitfall on Barro Colorado Island. Pages 151-172 in E. G. Leigh, A. S. Rand, and D. M. Windsor, editors. The ecology of a tropical forest: seasonal rhythms and long-term changes. Smithsonian Institute Press, Washington, D.C., USA.

Hammond, D. S. 1995. Post-dispersal seed and seedling mortality of tropical dry forest trees after shifting agriculture, Chiapas, Mexico. Journal of Tropical Ecology 11:295-313. Hammond, D. S., and V. K. Brown. 1995. Seed size of woody-plants in relation to disturbance, dispersal, soil type in wet Neotropical forests. Ecology 76:2544-2561.

Heske, E. J., J. H. Brown, and S. Mistry. 1994. Long-term experimental study of a Chihuahuan desert rodent community. Ecology 75:438-445.

Hoch, G. A., and G. H. Adler. 1997. Removal of Black Palm (Astrocaryum standleyanum) seeds by spiny rats (Proechimys semispinosus). Journal of Tropical Ecology 13:51-58. 
Howe, H. F., and J. S. Brown. 2001. The ghost of granivory past? Ecology Letters 4:371-378.

Hurtt, G. C., and S. W. Pacala. 1995. The consequences of recruitment limitation: reconciling chance, history, and competitive differences between plants. Journal of Theoretical Biology 176:1-12.

Janzen, D. 1971. Seed predation by animals. Annual Review of Ecology and Systematics 2:465-492.

Lambert, T. D., and G. H. Adler. 2000. Microhabitat use by a tropical forest rodent, Proechimys semispinosus in Central Panama. Journal of Mammalogy 81:70-76.

Lubchenco, J. 1978. Plant species diversity in a marine rocky intertidal community: importance of herbivore food preference and algal competitive abilities. American Naturalist 112:23-39.

Notman, E., D. L. Gorchov, and F. Cornejo. 1996. Effect of distance, aggregation, and habitat on levels of seed predation for two mammals-dispersed neotropical rain forest tree species. Oecologia 106:221-227.

Ostfled, R. S., and F. Keesing. 2000. Pulsed resources and community dynamics of consumers in terrestrial ecosystems. Trends in Ecology and Evolution 15:232-237.

Ostfeld, R., R. Manson, and C. Canham. 1997. Effects of rodents on survival of tree seeds and seedlings in invading old fields. Ecology 78:1531-1542.

Peña-Claros, M., and H. de Boo. 2002. The effect of forest successional stage on seed removal of tropical rain forest tree species. Journal of Tropical Ecology 18:261-274.

Peres, C. A. 2001. Synergistic effects of subsistence hunting and habitat fragmentation on Amazonian forest vertebrates. Conservation Biology 15:1490-1505.

Phillips, P. L. 1989. The relationship of successional and primary tropical forest to color infrared photography. Thesis. University of Texas at Austin, Austin, Texas, USA.

Rao, M., J. Terborgh, and P. Nunez. 2001. Increased herbivory in forest isolates: implications for plant community structure and composition. Conservation Biology 15:624633.

Reid, F. 1997. A field guide to the mammals of Central America and southeast Mexico. Oxford University Press, New York, New York, USA.
Richards, P. W. 1952. The tropical rain forest. Cambridge University Press, Cambridge, UK.

Schnurr, J. L., R. S. Ostfeld, and C. D. Canham. 2002. Direct and indirect effects of masting on rodent populations and tree seed survival. Oikos 96:402-410.

Soulé, M. E., and J. Terborgh. 1999. Continental conservation: scientific foundations of regional reserve networks. Island Press, Washington, D.C., USA.

Terborgh, J., L. Lopez, P. Nunez, M. Rao, G. Shahabuddin, G. Orihuela, M. Riveros, R. Ascanio, G. H. Adler, T. D. Lambert, and L. Balbas. 2001. Ecological meltdown in predator-free forest fragments. Science 294:1923-1926.

Terborgh, J., E. Losos, M. P. Riley, and M. B. Riley. 1993. Predation by vertebrates and invertebrates on the seeds of five canopy tree species of an Amazonian forest. Vegetatio 108:375-386.

Vandermeer, J. 1979. Seed dispersal of a common Costa Rican rain forest palm (Welfia georgii). Tropical Ecology 20: 17-26.

VanderWall, S. 1993. A model of caching depth: implications for scatterhoarders and plant dispersal. American Naturalist 141:317-332.

Wenny, D. G. 2000. Seed dispersal, seed predation, and seedling recruitment of a Neotropical montane tree. Ecological Monographs 70:331-351.

Whelan, C. J., M. F. Willson, C. A. Tuma, and I. Souza-Pinto. 1991. Spatial and temporal patterns of post dispersal seed predation. Canadian Journal of Botany 69:428-436.

Wills, C. 1996. Safety in diversity. New Scientist 149:3842.

Wright, S. J., and H. C. Duber. 2001. Poachers and forest fragmentation alter seed dispersal, seed survival, and seedling recruitment in the palm Attalea butyraceae with implications for tropical tree diversity. Biotropica 33:583595.

Wright, S. J., H. Zeballos, I. Dominguez, M. M. Gallardo, M. C. Moreno, and R. Banez. 2000. Poachers alter mammal abundance, seed dispersal, and seed predation in a Neotropical forest. Conservation Biology 14:227-239.

\section{APPENDIX A}

A comparison of seed predation treatments, differences in scatter-hoarding between large mammals and small rodents, and a comparison of seed predation between 2001 and 2002 are available in ESA's Electronic Data Archive: Ecological Archives E085-065-A1.

\section{APPENDIX B}

A table showing Cox regression results for 2001: all species is available in ESA's Electronic Data Archive: Ecological Archives E085-065-A2.

\section{APPENDIX C}

A table showing Cox regression results for 2001: differences among treatments is available in ESA's Electronic Data Archive: Ecological Archives E085-065-A3.

\section{APPENDIX D}

Differences in C. racemosa, B. costaricanum, and V. koshnyi seed predation rates in 2001 to 2002 and by treatment and by year are available in ESA's Electronic Data Archive: Ecological Archives E085-065-A4.

\section{APPENDIX E}

A diagram of terrestrial mammalian seed predation in the Neotropics is available in ESA's Electronic Data Archive: Ecological Archives E085-065-A5. 